\begin{tabular}{|c|c|}
\hline $\begin{array}{l}\text { Chemistry of } \\
\text { Metals and Alloys }\end{array}$ & $\begin{array}{l}\text { Chem. Met. Alloys } 6 \text { (2013) } 188-191 \\
\text { Ivan Franko Notional Universit of IViv } \\
\text { www..chemetal-journal. org }\end{array}$ \\
\hline
\end{tabular}

\title{
The $\mathrm{Cu}_{2} \mathrm{~S}-\mathrm{Cu}_{7} \mathrm{PS}_{6}-\mathrm{Cu}_{6} \mathrm{PS}_{5} \mathrm{I}$ quasiternary system
}

\author{
A.I. POGODIN ${ }^{1}$, I.E. BARCHIY ${ }^{1}$, A.P. KOKHAN $^{1} *$ \\ ${ }^{1}$ Faculty of Chemistry, Uzhhorod National University, Pidhirna St. 46, 88000 Uzhhorod, Ukraine \\ * Corresponding author. Tel.: +380-312-237163; fax: +380-312-235091; e-mail: alex-kokh@yandex.ru
}

Received November 6, 2013; accepted December 25, 2013; available on-line August 30, 2014

The $\mathrm{Cu}_{2} \mathrm{~S}-\mathrm{Cu}_{7} \mathrm{PS}_{6}-\mathrm{Cu}_{6} \mathrm{PS}_{5} \mathrm{I}$ quasiternary system was investigated by differential thermal analysis and $\mathrm{X}-\mathrm{ray}$ diffraction in combination with mathematical modeling. The phase diagram of the $\mathrm{Cu}_{7} \mathrm{PS}_{6}-\mathrm{Cu}_{6} \mathrm{PS}_{5} \mathrm{I}$ system, perspective views of the phase interactions in the ternary system, and a projection of the liquidus surface were constructed. New complex compounds do not form. The ternary system is of the invariant eutectic type and characterized by the formation of limited solid solutions. The three-dimensional one-, two- and threephase regions present in the $\mathrm{Cu}_{2} \mathrm{~S}-\mathrm{Cu}_{7} \mathrm{PS}_{6}-\mathrm{Cu}_{6} \mathrm{PS}_{5} \mathrm{I}$ system are described.

\section{Phase diagram / Thermal analysis / X-ray diffraction / Superionic conductors}

\section{Introduction}

The large family of chalcogenide and halidechalcogenide compounds called argyrodites (from the name of the mineral argyrodite, $\mathrm{Ag}_{8} \mathrm{GeS}_{6}$ ) [1] has been investigated for a long time, due to interesting physical and chemical properties: phase transitions at low temperatures, nonlinear ferroelectric properties, high ionic conductivity. Superionic conductivity in argyrodites is associated with $\mathrm{Ag}^{+}$and $\mathrm{Cu}^{+}$[2-4] in the cation sublattice. The $\mathrm{Cu}_{2} \mathrm{~S}-\mathrm{CuI}-\mathrm{P}_{2} \mathrm{~S}_{5}$ quasiternary system is interesting for the investigation of the presence of ternary and quaternary compounds belonging to the argyrodite family, which exhibit superionic properties and have practical application. Triangulation of $\mathrm{Cu}_{2} \mathrm{~S}-\mathrm{CuI}-\mathrm{P}_{2} \mathrm{~S}_{5}$ quasiternary system [5] divides it into four secondary quasiternary systems. The phase equilibria in the $\mathrm{Cu}_{2} \mathrm{~S}-\mathrm{CuI}-$ $\mathrm{Cu}_{6} \mathrm{PS}_{5} \mathrm{I}$ secondary quasiternary system have been studied previously [6]. Investigation of the $\mathrm{Cu}_{2} \mathrm{~S}-$ $\mathrm{Cu}_{7} \mathrm{PS}_{6}-\mathrm{Cu}_{6} \mathrm{PS}_{5} \mathrm{I}$ secondary quasiternary system is a necessary step in the study of the $\mathrm{Cu}_{2} \mathrm{~S}-\mathrm{CuI}-\mathrm{P}_{2} \mathrm{~S}_{5}$ quasiternary system, which may be characterized by the formation of complex compounds and solid solutions based on them.

\section{Experimental}

Synthesis of initial $\mathrm{Cu}_{2} \mathrm{~S}$ and $\mathrm{CuI}$ was carried out with high-purity elements (better than $99.99 \mathrm{wt} . \%$ ). The binary compounds were prepared by the single- and two-temperature method from stoichiometric amounts of the initial elements in evacuated quartz containers, and purified by the zone crystallization method. The
$\mathrm{Cu}_{7} \mathrm{PS}_{6}$ and $\mathrm{Cu}_{6} \mathrm{PS}_{5} \mathrm{I}$ ternary compounds and multicomponent alloys were synthesized from binary $\mathrm{Cu}_{2} \mathrm{~S}$ and $\mathrm{CuI}$ and elementary phosphorous and sulfur in quartz ampoules evacuated to a residual pressure of $0.13 \mathrm{~Pa}$. The highest synthesis temperature was $923 \mathrm{~K}$. After thermal treatment at the highest temperature for $120 \mathrm{~h}$, the samples were slowly cooled $(25-30 \mathrm{~K}$ per hour) to $573 \mathrm{~K}$ and homogenized at this temperature for $336 \mathrm{~h}$. Subsequently the ampoules were quenched in cold water. The samples were heated and cooled in a furnace equipped with an RIF-101 programmer, which provided a linear temperature variation. The phase equilibria in the ternary system were studied by classical methods of physico-chemical analysis, such as differential thermal analysis (Pt-Pt/Rh thermocouple with an accuracy of $\pm 5 \mathrm{~K}$ ) and X-ray powder diffraction (DRON-3, $\mathrm{Cu} K_{\alpha}$ radiation, $\mathrm{Ni}$ filter), in combination with the simplex method of mathematical modeling of phase equilibria in multicomponent systems [7]. This method provides good results and allows reducing the number of alloys synthesized in the ternary system.

\section{Results and discussion}

Based on the DTA and XRD results, the phase diagram of the $\mathrm{Cu}_{7} \mathrm{PS}_{6}-\mathrm{Cu}_{6} \mathrm{PS}_{5} \mathrm{I}$ system was constructed. It belongs to the Roozeboom type $\mathrm{V}$ (Fig. 1). It contains $\gamma$ - and $\gamma^{\prime}$-solid solution ranges of the low- (lt) and high-temperature (ht) modifications of $\mathrm{Cu}_{6} \mathrm{PS}_{5} \mathrm{I}$, and $\beta$ - and $\beta$ '-solid solution ranges of ltand ht- $\mathrm{Cu}_{7} \mathrm{PS}_{6}$, respectively. There exists a eutectic point (invariant process $\mathrm{L} \leftrightarrow \beta^{\prime}+\gamma^{\prime}$ ) in the system with the coordinates $85 \mathrm{~mol} \% \mathrm{Cu}_{7} \mathrm{PS}_{6}, 1254 \mathrm{~K}$. The extent 
of the $\beta^{\prime}$-solid solution range at the eutectic temperature is $65 \mathrm{~mol} . \% \mathrm{Cu}_{6} \mathrm{PS}_{5} \mathrm{I}$, that of the $\gamma^{\prime}$-solid solution range is $8 \mathrm{~mol} . \% \mathrm{Cu}_{6} \mathrm{PS}_{5} \mathrm{I}$. The peritectoid process on the basis of the polymorphous interaction of the $\mathrm{Cu}_{7} \mathrm{PS}_{6}$ ternary compound $\gamma^{\prime}+\beta \leftrightarrow \gamma$ takes place at $751 \mathrm{~K}$ (the coordinate of the peritectoid point is $\left.6 \mathrm{~mol} \% \mathrm{Cu}_{6} \mathrm{PS}_{5} \mathrm{I}\right)$. The peritectoid process on the basis of the polymorphous interaction of the $\mathrm{Cu}_{6} \mathrm{PS}_{5} \mathrm{I}$ ternary compound $\gamma^{\prime}+\beta^{\prime} \leftrightarrow \beta$ takes place at $756 \mathrm{~K}$ (the coordinate of the peritectoid point is $92 \mathrm{~mol} . \%$ $\left.\mathrm{Cu}_{6} \mathrm{PS}_{5} \mathrm{I}\right)$. The extent of the $\gamma$-solid solution range at $573 \mathrm{~K}$ is $15 \mathrm{~mol} . \% \mathrm{Cu}_{7} \mathrm{PS}_{6}$. At the same temperature the $\beta$-solid solution extends to $8 \mathrm{~mol} \% \mathrm{Cu}_{6} \mathrm{PS}_{5} \mathrm{I}$.

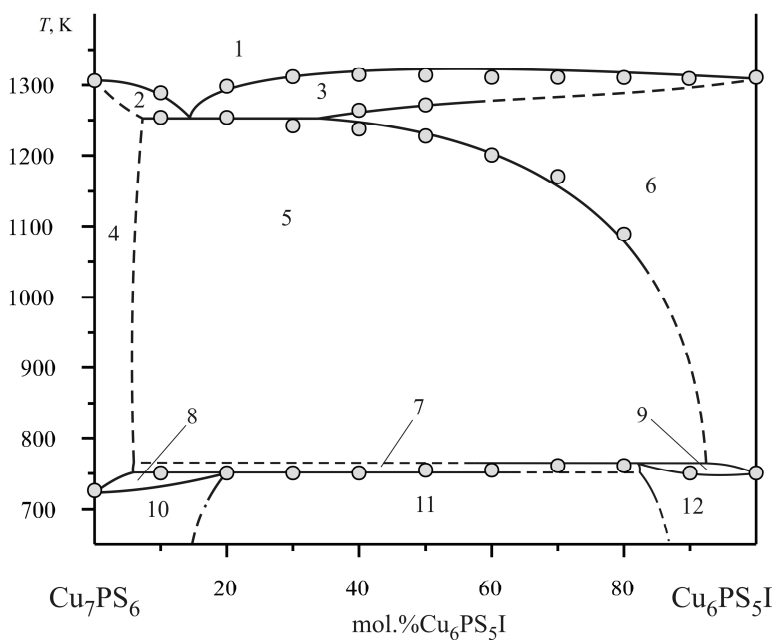

Fig. 1 Phase diagram of the $\mathrm{Cu}_{7} \mathrm{PS}_{6}-\mathrm{Cu}_{6} \mathrm{PS}_{5} \mathrm{I}$ system: (1) L, (2) L+ $\gamma^{\prime}$, (3) L+ $\beta^{\prime}$, (4) $\gamma^{\prime}$, (5) $\gamma^{\prime}+$ $\beta^{\prime}$, , (6) $\beta^{\prime}$, (7) $\gamma^{\prime}+\beta$, (8) $\gamma+\gamma^{\prime}$, (9) $\beta+\beta^{\prime}$, (10) $\gamma$, (11) $\gamma+\beta$, (12) $\beta$.

Based on the results of the investigation by DTA and the simplex method, a projection of the $\mathrm{Cu}_{2} \mathrm{~S}-$ $\mathrm{Cu}_{7} \mathrm{PS}_{6}-\mathrm{Cu}_{6} \mathrm{PS}_{5} \mathrm{I}$ liquidus surface onto the concentration triangle was constructed (Fig. 2). The liquidus of the system consists of three primary crystallization areas: the $\alpha$ '-phase (bordered by $\mathrm{Cu}_{2} \mathrm{~S}-$ e1-E-e2- $\mathrm{Cu}_{2} \mathrm{~S}$ ), $\beta$ ' - phase (bordered by $\mathrm{Cu}_{6} \mathrm{PS}_{5} \mathrm{I}-\mathrm{e} 1-$ E-e3- $\mathrm{Cu}_{6} \mathrm{PS}_{5} \mathrm{I}$ ) and $\gamma^{\prime}$-phase (bordered by $\mathrm{Cu}_{7} \mathrm{PS}_{6}-$
e2-E-e3- $\left.\mathrm{Cu}_{7} \mathrm{PS}_{6}\right)$. The fields of primary crystallization are divided by three monovariant lines: e1-E (temperature range 1233-1219 K), e2-E (temperature range 1260-1219 K), e3-E (temperature range $1254-1219 \mathrm{~K})$, which cross at the ternary invariant eutectic point $\mathrm{E}\left(\mathrm{L} \leftrightarrow \alpha^{\prime}+\beta^{\prime}+\gamma^{\prime}\right)$.

The lines of the monovariant equilibria were described using polynomial analyses of vertical sections. For example, the results of the analysis of the section a1-a1' $\left(5 \mathrm{~mol} \% \mathrm{Cu}_{2} \mathrm{~S}\right)$ are shown in Fig. 3 and Table 1 . The primary crystallization of the $\beta$ ' - and $\gamma$ '-phases is described by a polynomial $Y=\mathrm{a}_{0}+\mathrm{a}_{1} X+\mathrm{a}_{2} X^{2}+\mathrm{a}_{3} X^{3}$ ( $Y$ represents the temperature of crystallization in $\mathrm{K}, X$ is the concentration in mol. $\%$, and $\mathrm{a}_{0}, \mathrm{a}_{1}, \mathrm{a}_{2}, \mathrm{a}_{3}$ are polynomial coefficients). The polynomial curves cross at a point situated on the e3-E monovariant line of the $\mathrm{Cu}_{2} \mathrm{~S}-\mathrm{Cu}_{7} \mathrm{PS}_{6}-\mathrm{Cu}_{6} \mathrm{PS}_{5} \mathrm{I}$ quasiternary system. It should be noted that the results of the calculations showed good agreement with the experimental data (correlation parameter $r_{x y} 0.9963$ 0.9999; root mean square deviation 0.2963-5.1976).

The coordinates of the invariant eutectic point $(\mathrm{E})$ was determined by computer modeling using the simplex method: 60 mol. $\% \mathrm{Cu}_{2} \mathrm{~S}, 34$ mol. $\% \mathrm{Cu}_{7} \mathrm{PS}_{6}$, $6 \mathrm{~mol} . \% \mathrm{Cu}_{6} \mathrm{PS}_{5} \mathrm{I}, 1219 \mathrm{~K}$.

A perspective view of the $\mathrm{Cu}_{2} \mathrm{~S}-\mathrm{Cu}_{7} \mathrm{PS}_{6}-\mathrm{Cu}_{6} \mathrm{PS}_{5} \mathrm{I}$ quasiternary system is shown in Fig. 4. The points A", B" and C", which are located at the edges of a ternary prism, represent the melting temperature of the three components $\left(\mathrm{Cu}_{6} \mathrm{PS}_{5} \mathrm{I}-1311 \mathrm{~K}, \mathrm{Cu}_{2} \mathrm{~S}-1396 \mathrm{~K}\right.$, $\mathrm{Cu}_{7} \mathrm{PS}_{6}-1318 \mathrm{~K}$ ). Limited solid solutions form in the system: $\alpha$ - and $\alpha^{\prime}$-phases based on the lt- and htmodifications of $\mathrm{Cu}_{2} \mathrm{~S}, \beta$ - and $\beta$ '-phases based on the lt- and ht-modifications of $\mathrm{Cu}_{6} \mathrm{PS}_{5} \mathrm{I}, \gamma$-and $\gamma^{\prime}$-phases on the lt- and ht-modifications of $\mathrm{Cu}_{7} \mathrm{PS}_{6}$. The faces of the ternary prism belong to the three binary eutectic type systems $\mathrm{Cu}_{2} \mathrm{~S}-\mathrm{Cu}_{6} \mathrm{PS}_{5} \mathrm{I}, \quad \mathrm{Cu}_{2} \mathrm{~S}-\mathrm{Cu}_{7} \mathrm{PS}_{6}$ and $\mathrm{Cu}_{7} \mathrm{PS}_{6}-\mathrm{Cu}_{6} \mathrm{PS}_{5} \mathrm{I}$, which are characterized by the invariant eutectic processes $L \leftrightarrow \alpha^{\prime}+\beta^{\prime}$ (coordinates of the eutectic point e1: 20 mol.\% $\mathrm{Cu}_{6} \mathrm{PS}_{5} \mathrm{I}, 1233 \mathrm{~K}$ ), $\mathrm{L} \leftrightarrow \alpha^{\prime}+\gamma^{\prime}$ (coordinates of the eutectic point e2: 50 mol. $\% \mathrm{Cu}_{7} \mathrm{PS}_{6}, 1260 \mathrm{~K}$ ), and $\mathrm{L} \leftrightarrow \beta^{\prime}+\gamma^{\prime}$ (coordinates of the eutectic point e3: $85 \mathrm{~mol} \% \mathrm{Cu}_{7} \mathrm{PS}_{6}, 1254 \mathrm{~K}$ ), respectively.

Table 1 Results of polynomial calculations for the a1-a1' section (10 mol.\% $\left.\mathrm{Cu}_{2} \mathrm{~S}\right)$.

\begin{tabular}{c|c|l|c|c|c}
\hline \multicolumn{5}{c}{ Fields of primary crystallization } \\
\hline \multicolumn{3}{c}{$\beta^{\prime}$-phase (based on ht-Cu ${ }_{6} \mathrm{PS}_{5} \mathrm{I}$ ) } & \multicolumn{3}{c}{$\gamma^{\prime}$-phase (based on ht-Cu $\mathrm{Cu}_{7} \mathrm{PS}_{6}$ ) } \\
\hline mol.\% a1' & $T, \mathrm{~K}$ & \multicolumn{1}{c}{ Polynomial parameters } & mol.\% a1' & $T, \mathrm{~K}$ & \multicolumn{1}{c}{ Polynomial parameters } \\
\hline 0 & 1305 & $\mathrm{a}_{0}=1304.60$ & 85.6 & 1250 & $\mathrm{a}_{0}=-1666.19$ \\
15.2 & 1302 & $\mathrm{a}_{1}=7.81 \times 10^{-2}$ & 88.6 & 1275 & $\mathrm{a}_{1}=58.82$ \\
36.4 & 1295 & $\mathrm{a}_{2}=-1.17 \times 10^{-2}$ & 92.4 & 1300 & $\mathrm{a}_{2}=-0.29$ \\
54.5 & 1278 & $\mathrm{a}_{3}=2.91 \times 10^{-5}$ & 100 & 1324 & \\
81.1 & 1250 & $r_{x y}=0.9988$ & & & $r_{x y}=0.9999$ \\
& & $S_{x y}=2.2534$ & & & $S_{x y}=0.2962$ \\
\hline
\end{tabular}

Point of intersection: 84.8 mol. $\%$ al'; $T=1245 \mathrm{~K}$. 


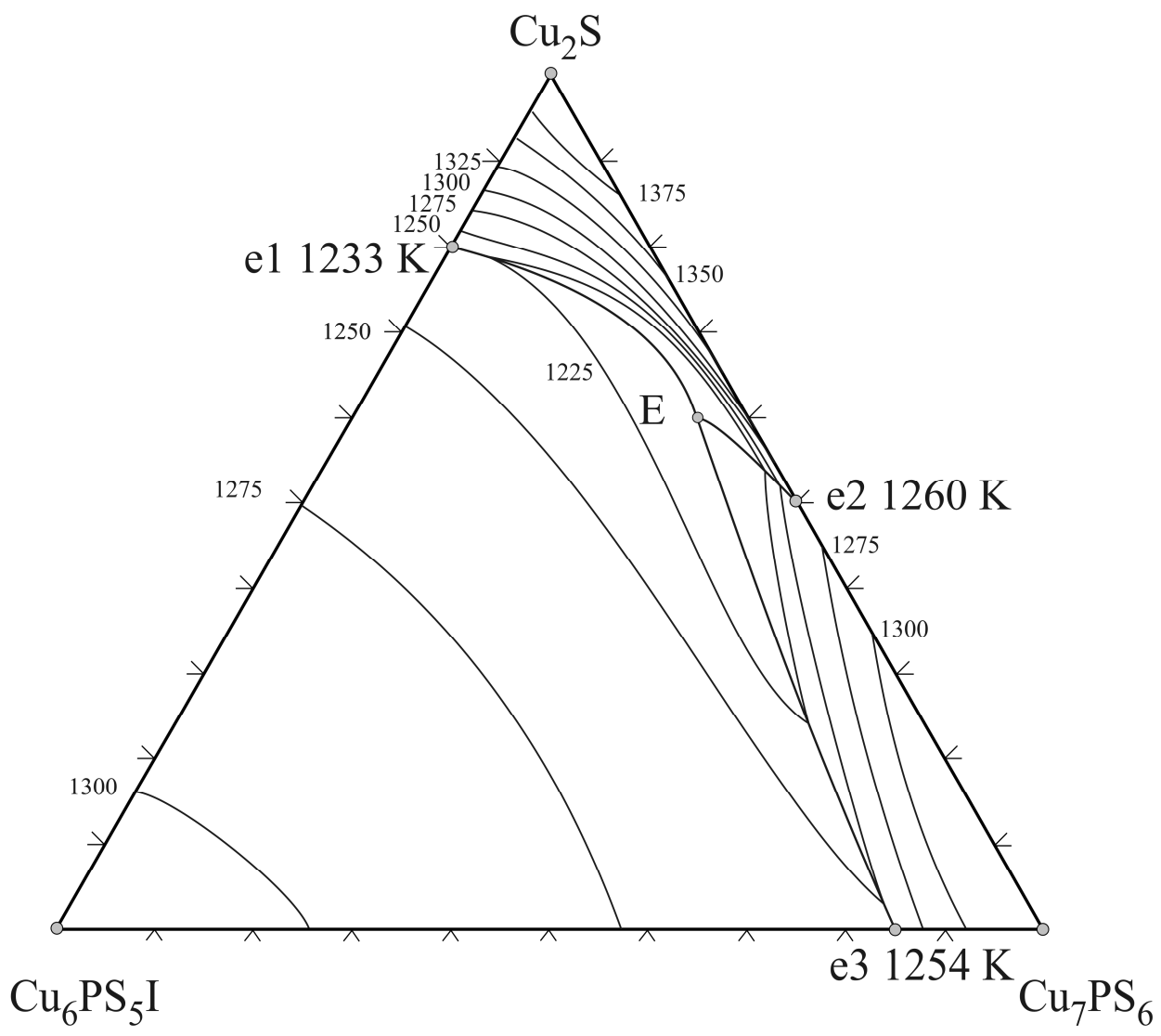

Fig. 2 Liquidus projection of the $\mathrm{Cu}_{2} \mathrm{~S}-\mathrm{Cu}_{7} \mathrm{PS}_{6}-\mathrm{Cu}_{6} \mathrm{PS}_{5} \mathrm{I}$ quasiternary system.

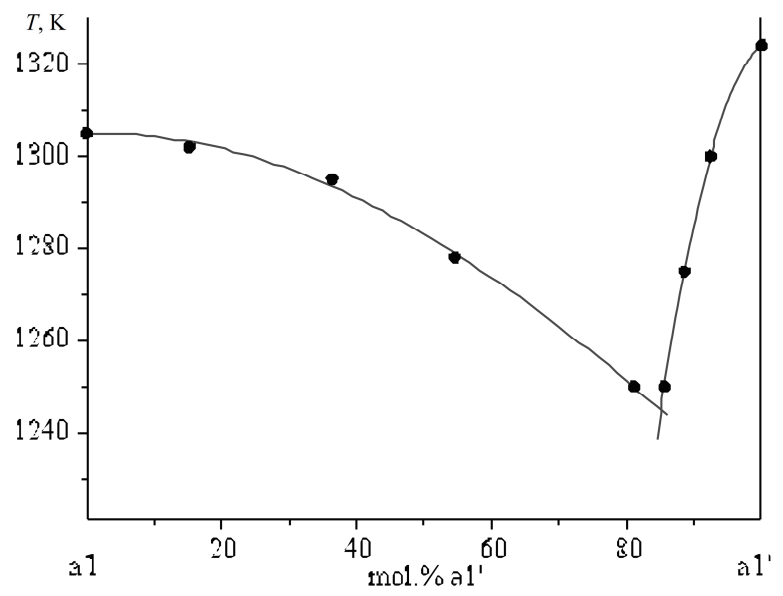

Fig. 3 Polynomial curves of primary crystallization of the $\beta$ '- and $\gamma^{\prime}$-phases (vertical section along the a1-al' section, 10 mol.\% $\left.\mathrm{Cu}_{2} \mathrm{~S}\right)$.

The system liquidus is characterized by the following surfaces of primary crystallization: $\alpha$ '-phase (bordered by B"-e1-E-e2-B"), $\beta$ '-phase (bordered by A"-e1-E-e3-A") and $\gamma^{\prime}$-phase (bordered by
C"-e2-E-e3-C"). The lines of the monovariant processes $(\mathrm{e} 1-\mathrm{E}, \mathrm{e} 2-\mathrm{E}$ and $\mathrm{e} 3-\mathrm{E})$ intersect in the invariant eutectic point $\mathrm{E}\left(\mathrm{L} \leftrightarrow \alpha^{\prime}+\beta^{\prime}+\gamma^{\prime}\right)$. The system solidus consists of the following fields: A"-a1-a11a6-A" (end of $\beta$ '-phase crystallization), B"-b1-b11b6-B" (end of $\alpha$ '-phase crystallization), C"-c1-c11c6-C' (end of $\gamma^{\prime}$-phase crystallization), a1-b1-b11a11-a1 (end of crystallization of $\alpha^{\prime}+\gamma^{\prime}$ ), a6-a11-b11b6-a6 (end of crystallization of both $\alpha^{\prime}+\beta^{\prime}$ ), b6-c1c11-b11-b6 (end of crystallization of $\beta^{\prime}+\gamma^{\prime}$ ), and a triangular surface of ternary eutectic processes a11b11-c11-a11. In the subsolidus area, three invariant surfaces represent the polymorphous interactions of $\mathrm{Cu}_{2} \mathrm{~S}$ (b14-a14-c14-b14) at $628 \mathrm{~K}, \mathrm{Cu}_{7} \mathrm{PS}_{6}$ (c13-a13b13-c13) at $781 \mathrm{~K}$, and $\mathrm{Cu}_{6} \mathrm{PS}_{5} \mathrm{I}$ (a12-b12-c12-a12) at $803 \mathrm{~K}$.

The type, temperature and coordinates of the invariant processes in the $\mathrm{Cu}_{2} \mathrm{~S}-\mathrm{Cu}_{7} \mathrm{PS}_{6}-\mathrm{Cu}_{6} \mathrm{PS}_{5} \mathrm{I}$ quasiternary system are listed in Table 2.

The X-ray analysis of $\mathrm{Cu}_{2} \mathrm{~S}-\mathrm{Cu}_{7} \mathrm{PS}_{6}-\mathrm{Cu}_{6} \mathrm{PS}_{5} \mathrm{I}$ alloys of the isothermal section at $573 \mathrm{~K}$ confirmed that the extent of the homogeneity regions of the $\beta$ and $\gamma$-phases corresponds to $8-15$ mol.\%, whereas that of the $\alpha$-phase is not more than 5 mol.\%. New complex compounds were not observed in the ternary system. 


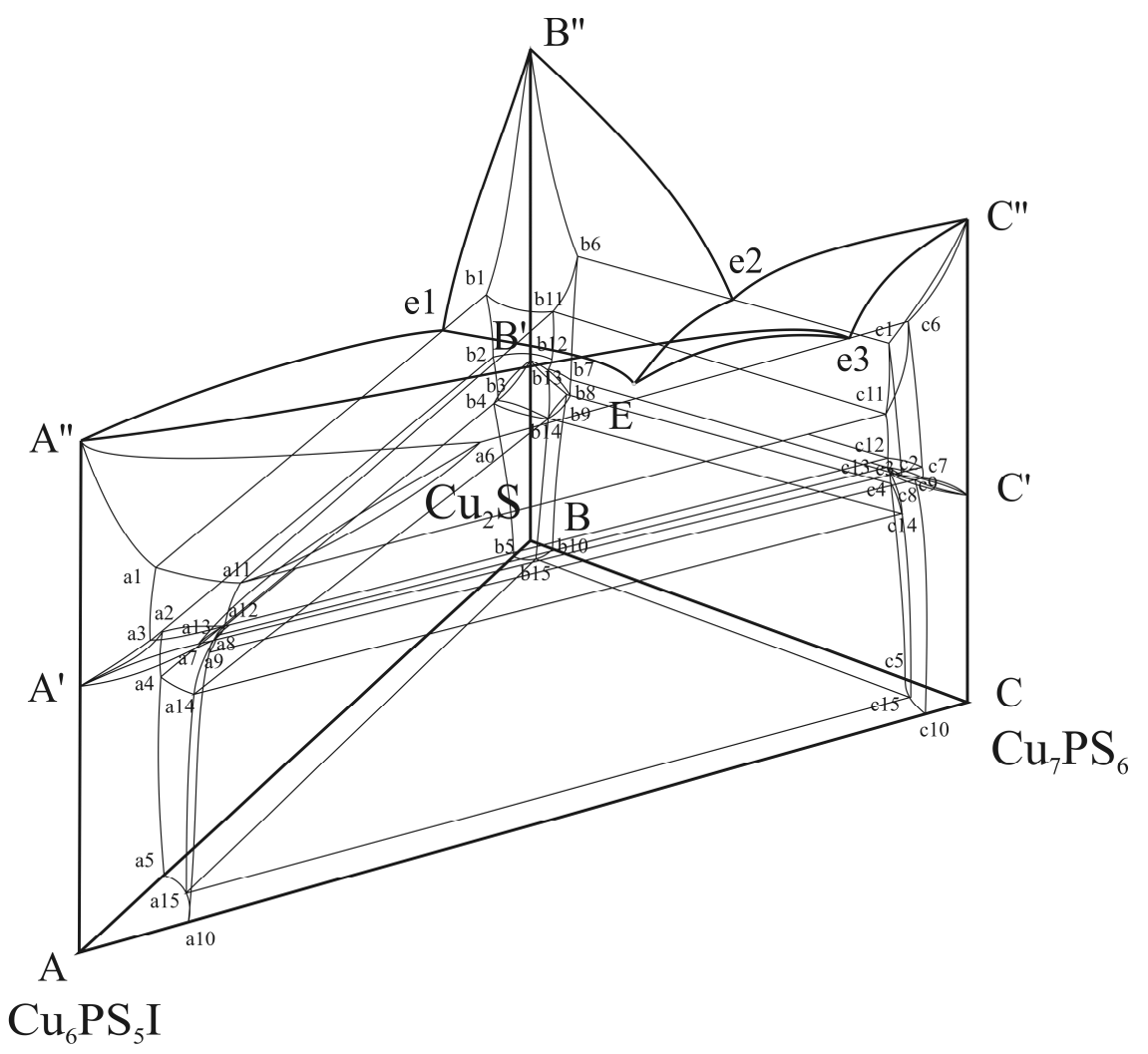

Fig. 4 Perspective view of the $\mathrm{Cu}_{2} \mathrm{~S}-\mathrm{Cu}_{7} \mathrm{PS}_{6}-\mathrm{Cu}_{6} \mathrm{PS}_{5} \mathrm{I}$ quasiternary system.

Table 2 Type, temperature and coordinates of the invariant processes in the $\mathrm{Cu}_{2} \mathrm{~S}-\mathrm{Cu}_{7} \mathrm{PS}_{6}-\mathrm{Cu}_{6} \mathrm{PS}_{5} \mathrm{I}$ quasiternary system.

\begin{tabular}{l|l|c|c|c|c}
\hline \multirow{2}{*}{ Type } & \multicolumn{1}{c|}{ Process } & \multirow{2}{*}{$T, \mathrm{~K}$} & \multicolumn{3}{|c}{ Coordinates, mol.\% } \\
\cline { 5 - 7 } & & & $\mathrm{Cu}_{2} \mathrm{~S}$ & $\mathrm{Cu}_{7} \mathrm{PS}_{6}$ & $\mathrm{Cu}_{6} \mathrm{PS}_{5} \mathrm{I}$ \\
\hline Binary invariant eutectic & $\mathrm{e} 1\left(\mathrm{~L} \leftrightarrow \alpha^{\prime}+\beta^{\prime}\right)$ & 1233 & 80 & - & 20 \\
Binary invariant eutectic & $\mathrm{e} 2\left(\mathrm{~L} \leftrightarrow \alpha^{\prime}+\gamma^{\prime}\right)$ & 1260 & 50 & 50 & - \\
Binary invariant eutectic & $\mathrm{e} 3\left(\mathrm{~L} \leftrightarrow \beta^{\prime}+\gamma^{\prime}\right)$ & 1254 & - & 85 & 15 \\
Ternary invariant eutectic & $\mathrm{E}\left(\mathrm{L} \leftrightarrow \alpha^{\prime}+\beta^{\prime}+\gamma^{\prime}\right)$ & 1219 & 60 & 34 & 6 \\
\hline
\end{tabular}

\section{Conclusions}

Differential thermal analysis, X-ray diffraction and mathematical modeling of the phase equilibria in the multicomponent systems by the simplex method were used to construct for the first time the phase diagram of the $\mathrm{Cu}_{7} \mathrm{PS}_{6}-\mathrm{Cu}_{6} \mathrm{PS}_{5} \mathrm{I}$ system, a perspective representation of the $\mathrm{Cu}_{2} \mathrm{~S}-\mathrm{Cu}_{7} \mathrm{PS}_{6}-\mathrm{Cu}_{6} \mathrm{PS}_{5} \mathrm{I}$ quasiternary system and a projection of the liquidus surface onto the concentration triangle. The character of the monovariant processes, and the temperatures and coordinates of the invariant processes in the ternary system were determined. The system is characterized by the invariant eutectic process $\mathrm{L} \leftrightarrow \alpha^{\prime}+\beta^{\prime}+\gamma^{\prime} \quad\left(60 \mathrm{~mol} . \% \mathrm{Cu}_{2} \mathrm{~S}\right.$, $\left.34 \mathrm{~mol} . \% \mathrm{Cu}_{7} \mathrm{PS}_{6}, \quad 6 \mathrm{~mol} \% \quad \mathrm{Cu}_{6} \mathrm{PS}_{5} \mathrm{I}, \quad 1219 \mathrm{~K}\right)$. The existence of solid solutions of the $\mathrm{Cu}_{2} \mathrm{~S}, \mathrm{Cu}_{7} \mathrm{PS}_{6}$, and $\mathrm{Cu}_{6} \mathrm{PS}_{5} \mathrm{I}$ compounds was established. New complex compounds were not observed in the ternary system.

\section{References}

[1] W.F. Kuhs, R. Nitsche, K. Scheunemann, Mater. Res. Bull. 14(2) (1979) 241-248.

[2] R. Belin, L. Aldon, A. Zerouale, C. Belin, M. Ribes, Solid State Sci. 3 (2001) 251-265.

[3] I.P. Studenyak, M. Kranjčec, G.S. Kovacs, I.D. Desnica-Franković, A.A. Molnar, V.V. Panko, V.Y. Slivka, J. Phys. Chem. Solids 63 (2002) 267-271.

[4] T. Nilges, A. Pfitzner, Z. Kristallogr. 220 (2005) 281-294.

[5] A.I. Pogodin, O.P. Kokhan, Visn. Uzhhorod. Nat. Univ., Ser. Khim. 26 (2011) 23-25.

[6] A.I. Pogodin, O.P. Kokhan, I.E. Barchiy, $U k r$. Khim. Zh. 78(12) (2012) 22-26.

[7] I.E. Barchiy, Ukr. Khim. Zh. 67(11) (2001) 18-23. 